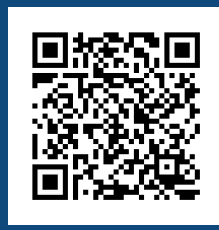

Gardênia Proto Dias ${ }^{\mathrm{a}+}$, Arthur Almeida Rodrigues ${ }^{\mathrm{lb}}$, Andreia Mendes da Costa ${ }^{\mathrm{lc}}$, Leandro Carlos $^{\text {Id }}$,Sebastião Carvalho Vasconcelos Filho'e, Priscila Ferreira Batistalf

\title{
MORPHOLOGICAL, ANATOMICAL AND PHYSIOLOGICAL CHARACTERISTICS OF Acrocarpus fraxinifolius WIGHT \& ARN SEEDLINGS ACCORDING TO CONTAINERS AND FERTILIZATION
}

DIAS, G. P., RODRIGUES, A. A, COSTA, A. M., CARLOS, L.,VASCONCELOS FILHO, S. C., BATISTA, P. F. Morphological, anatomical and physiological characteristics of Acrocarpus fraxinifolius Wight \& Arn seedlings according to containers and fertilization. CERNE, v. 24, n. 4, p. 430-438, 2018.

\section{HIGHLIGHTS}

Keywords:

Pink cedar

Split fertilization

Photosynthesis

Leaf morphology

Osmocote ${ }^{\circledR}$

Historic:

Received 29/08/2018

Accepted 13/10/2018

Correspondence:

leandro.carlos@ifgoiano.edu.br

Acrocarpus fraxinifolius plants show increased growth and stem diameter when grown in II 0 $\mathrm{cm}^{3}$ tubes.

Photosynthetic rate (A), stomatal conductance (gs) and transpiration (E) of Acrocarpus fraxinifolius in $110 \mathrm{~cm}^{3}$ tubes were similar to well-fertilized $50 \mathrm{~cm}^{3}$ tubes.

The plants demonstrated expansion of Parenchyma cells with greater mesophyll thickness.

\section{ABSTRACT}

The production of quality seedlings coupled with the correct choice of fertilizer doses/ sources and the container type are essential in the planting of forest species. Thus, the objective of this study was to evaluate the relationship between morphological, physiological and anatomical characteristics and container volume with different fertilizations on Acrocarpus fraxinifolius seeds seedlings. The experiment was conducted in a $2 \times 8$ factorial scheme (2 volumes of containers and 8 fertilizations), tested in polypropylene tubes of 50 and $110 \mathrm{~cm}^{3}$ and according to different fertilizations: control without fertilization; 4 increasing doses of Osmocote ${ }^{\circledR}$ Plus: $3,5,7,9 \mathrm{~kg} \cdot \mathrm{per} \cdot \mathrm{m}^{3}$ of substrate, respectively; and 3 split mineral fertilizers with coverings. It was possible to note that the tube with the greatest volume of $110 \mathrm{~cm}^{3}$ presented the best results regarding the morphological characteristics, however, when analyzing the physiological variables it was clear that the $50 \mathrm{~cm}^{3}$ tubes present similar results to those of larger volume when well fertilized. Split fertilization presented better results than slow-release fertilization, and 50 $\mathrm{cm}^{3}$ tubes were more sensitive to fertilization due to the lower volume. Thus, the use of $50 \mathrm{~cm}^{3}$ tubes with fertilization is recommended for producing A. fraxinifolius seedlings, due to presenting physiological quality and economy of inputs in nursery production, transportation and planting.

' Goiano Federal Institute of Education, Science and Technology, Campus Rio Verde, Rio Verde, Goiás, Brazil- ORCID:

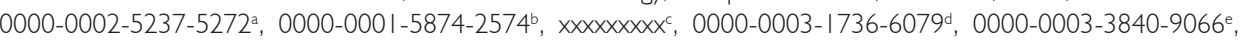
$0000-0002-2061-7062^{f}$ 


\section{INTRODUCTION}

Environmental policies employed in many countries around the world strongly promote the conversion of land into forests as an effective measure to mitigate climate change and protect biodiversity (Rudawska et al., 2017). In addition, the demand for products of forest origin has increased in recent decades, demanding alternatives of forest species with high productivity (Thebaldi et al., 20I5), as well as the introduction of species which are already known in other countries that have potential for forest restoration and landscaping projects indicated for urban afforestation (Venturin et al., 20l4). Thus, the search for species with silvicultural potential is increasingly higher in order to meet market trends, higher productivity and site quality (Klippel et al., 20I3).

In Brazil, the introduction of forest species from other countries is of fundamental importance, not only to reduce the forest deficit but also to protect native fragments for carbon sequestration (Klippel et al., 2013; Venturin et al., 20l4). In this sense, the production of high-quality seedlings is of great importance for establishing forest plantations, and which requires the understanding of seedling nutrition, the use of the appropriate substrate, as well as the most appropriate container/tube size (Caione et al., 20l2).

As tubes for forest species are generally small in size, studies on the nutrition in these plants and the application of nutrients are extremely important, and nitrogen, phosphorus and potassium in the growth of the seedlings have especially aroused the interest of several forest researchers (Simões et al., 20I5; Caione et al., 20I2). Moreover, these nutrients can be supplied by splited supply through cover fertilization or fertirrigation, or via slow or controlled-release fertilizers, which can be an efficient alternative for plant production (Dinalli et al., 20I2).

There is a gap in the knowledge of anatomical and physiological characteristics in developing and establishing seedlings of different forest species in relation to their nutrition, given that certain nutrients increase the productivity of plants due to their participation in the structures and vital processes, reflecting in cell division and expansion, thus aiding the growth of shoots and roots (Turchetto et al., 2016).

Acrocarpus fraxinifolius Wight \& Arn belongs to the Fabaceae family, Caesalpinioideae subfamily, and it is popularly known as Pink cedar. It produces a reddishbrown hard wood used for construction, furniture and pulp production (Firmino et al., 2015). It is native to high rainfall regions of Asia, has rapid growth, it is very promising for reforestation, and used for producing short rotation timber (Trianoski et al., 20II). It occurs more specifically in perennial forests of India, Bangladesh, Indonesia, Nepal and Myanmar (Venturin et al., 20l4). In addition, the cedar tree has economic potential for establishing productive plantations (Nisgoski et al., 20I2). However, to date there are no studies on the quality of $A$. fraxinifolius seedlings in different containers and fertilization, evidencing its effects on physiology and anatomical structure. Thus, the objective of this study was to evaluate the relationship between the volume of containers and different fertilizations, on anatomical and physiological characteristics of $A$. fraxinifolius seedlings.

\section{MATERIAL AND METHODS}

\section{Plant Material, Cultivation Conditions and Treatments}

Acrocarpus fraxinifolius seeds were collected and benefited according to the recommendations by Davide \& Silva (2008), from 10 adult plants in full production, located at the Federal University of Lavras. The seeds were subsequently treated with concentrated sulfuric acid for ten minutes in order to break seed dormancy (Rai, 1976). The seedlings were produced in the nursery of the Tissue Culture Laboratory of the Instituto Federal Goiano, Campus Rio Verde. The climate of the region is Aw (Köppen), with mild summers and dry winters. The annual precipitation and temperature averages are $1652 \mathrm{~mm}$ and $23.2^{\circ} \mathrm{C}$, respectively (BRASIL, 1992; INMET, 20I2).

The substrate used for seedling formation was composed of a mixture of $25 \%$ carbonized rice husk, $25 \%$ expanded vermiculite, $25 \%$ poultry manure and $25 \%$ sludge of swine wastewater. After the substrate was prepared, the base fertilizer was placed in the tubes. The tubes were subsequently filled with the substrate and the seeds were sown. Three seeds were used for each tube which were thinned after germination, leaving only one plant per tube. Two polypropylene tube sizes were tested (50 and $\left.110 \mathrm{~cm}^{3}\right)$. The tubes were sanitized with $1 \%$ sodium hypochlorite for disinfection prior to use.

The experiment consisted of eight basal substrate fertilizations; one was the control without fertilization, while four had increasing doses of osmocote plus for 3-4 months (I5-09-12): 3, 5, 7, and $9 \mathrm{~kg}$ of osmocote per $\mathrm{m}^{3}$ of substrate respectively, and three mineral fertilizations composed of: one dose, a half dose and a double dose of the mineral fertilization recommendation proposed by Gonçalves and Benedetti (2005), which consists of I50g doses of $\mathrm{N}, 300 \mathrm{~g}$ of $\mathrm{P}_{2} \mathrm{O}_{5}, 150 \mathrm{~g}$ of $\mathrm{K}_{2} \mathrm{O}$ and $150 \mathrm{~g}$ of "FTE Fritted Trace Elements" (micronutrient cocktail in the form of silicate oxides) per 10,000 seedlings, as shown in Table I. 
TABLE I Base and Coverage fertilization treatments applied to Acrocarpus fraxinifolius seedlings in this experiment.

\begin{tabular}{|c|c|c|}
\hline Treatment* & Base fertilization & Coverage fertilization \\
\hline TI & 0 & No \\
\hline T2 & $\begin{array}{c}3 \mathrm{~kg} \text { of osmocote / } \\
\mathrm{m}^{3} \text { of substrate }\end{array}$ & No \\
\hline T3 & $\begin{array}{c}5 \mathrm{~kg} \text { of osmocote / } \\
\mathrm{m}^{3} \text { of substrate }\end{array}$ & No \\
\hline T4 & $\begin{array}{c}7 \mathrm{~kg} \text { of osmocote / } \\
\mathrm{m}^{3} \text { of substrate }\end{array}$ & No \\
\hline T5 & $\begin{array}{c}9 \mathrm{~kg} \text { of osmocote / } \\
\mathrm{m}^{3} \text { of substrate }\end{array}$ & No \\
\hline T6 & Half of T7 & Half of T7 \\
\hline T7 & $\begin{array}{c}150 \mathrm{mg} \cdot \mathrm{dm}^{-3} \text { of } \mathrm{N}, \\
300 \mathrm{mg} \cdot \mathrm{dm}^{-3} \text { of } \mathrm{P} 2 \mathrm{O} \text {, } \\
150 \mathrm{mg} \mathrm{dm} \text { of } \mathrm{K} \mathrm{O} \text { and } \\
150 \mathrm{mg} \cdot \mathrm{dm}^{-3} \text { of } \mathrm{FTE} \mathrm{Br} / 2\end{array}$ & $\begin{array}{c}20 \mathrm{mg} \text { of } \mathrm{N} \text { and } 15 \mathrm{mg} \\
\text { of } \mathrm{K}_{2} \mathrm{O} \text { per tube*** }\end{array}$ \\
\hline T8 & Double of T7 & Double of T7 \\
\hline
\end{tabular}

All fertilization treatments are in factorial for two container volumes (50 and I I0 $\left.\mathrm{cm}^{3}\right)$. **N was applied weekly and $\mathrm{K}_{2} \mathrm{O}$ at every two weeks, starting 30 days after germination..

Seedling growth was carried out under full sun using an automatic irrigation system $\left(4.3 \mathrm{l} \cdot \mathrm{m}^{-2}\right.$, three times a day). The mineral nutrient fertilization of $100 \mathrm{~g}$ of $\mathrm{N}$ and $\mathrm{IOOg}$ of $\mathrm{K}_{2} \mathrm{O}$ was initiated 30 days after germination, in which Treatment 6 received half of this dosage, Treatment 7 received the equivalent of a single dosage and Treatment 8 received a double dosage, according to the recommendations of Gonçalves and Benedetti (2005). The application intervals were alternated with a first application of ammonium sulphate and potassium chloride; seven days later, only ammonium sulphate was applied; the following week both ammonium sulfate and potassium chloride were applied, and so forth. Therefore, cover fertilization was not performed in the controlled release fertilizer, since in theory it provides nutrients throughout the plant cycle.

Morphological characteristics were evaluated at 120 days after sowing: shoot height $(\mathrm{H})$ and stem diameter (D). A millimeter ruler was used for height measurements $(H)$, and a digital caliper was used for measuring diameter at $0.5 \mathrm{~cm}$ height of the substrate (D).

\section{Experimental design}

The experiment was implemented according to a completely randomized design following a $2 \times 8$ factorial scheme ( 2 container volumes and 8 fertilizations), 3 replicates and 20 seedlings per plot, with a total of 48 plots. The seedlings were alternately arranged in the trays in order to avoid competition between individuals.

\section{Gas exchanges}

Gas exchanges were evaluated in the last fully expanded leaf, recording stomatal conductance [gs, mol $\left.\left(\mathrm{H}_{2} \mathrm{O}\right) \mathrm{m}^{-2} \cdot \mathrm{s}^{-1}\right]$, photosynthetic rate $\left[A, \mu \mathrm{mol}\left(\mathrm{CO}_{2}\right) \mathrm{m}^{-2} \cdot \mathrm{s}^{-}\right.$ '], transpiration $\left[E, \mathrm{mmol}\left(\mathrm{H}_{2} \mathrm{O}\right) \mathrm{m}^{-2} \cdot \mathrm{s}^{-1}\right]$, and internal and external $\mathrm{CO}_{2}$ concentration $(\mathrm{Ci} / \mathrm{Ca})$. These evaluations were performed using a LI6400xt (IRGA) portable infrared gas analyzer (Li-Cor, Nebraska, USA), with a photon flux density of $1000 \mu \mathrm{mol} . \mathrm{m}^{-2} . \mathrm{s}^{-1}$, between 08:00am and 12:00pm.

\section{Evaluation of chlorophyll a fluorescence}

The variables for chlorophyll $a$ fluorescence were evaluated on the same sheet in which the gas exchange data were evaluated, and using a MINI-PAM modulated portable fluorometer (Walz ${ }^{\circledR}$, Effeltrich, Germany) equipped with a special 2030-B clamp for leaf support. The potential quantum yield of photosystem II (Fv/Fm) was calculated after 30 minutes of dark adaptation. The effective quantum yield of photosystem II ( $\left.\Delta F / F m^{\prime}\right)$ was determined by superimposing a saturation pulse on leaves previously adapted to ambient light. The $\Delta \mathrm{F} / \mathrm{Fm}$ ' was used to estimate the apparent electron transport rate $\left(\mathrm{ETR}, \mathrm{mmol} \cdot \mathrm{m}^{-2} \cdot \mathrm{s}^{-1}\right)$ (LAISK \& LORETO, 1996) and the non-photochemical extinction coefficient (NPQ) was calculated according to Bilger \& Bjorkman (1990).

\section{Morphoanatomic characterization of the leaf}

Regarding the morphoanatomical analysis, $3 \mathrm{~cm}^{2}$ leaf samples were collected from the central region of the last fully expanded leaf of all replicates $(n=4)$ of each treatment $(n=5)$ from Acrocarpus fraxinifolius plants. The samples were initially fixed in Karnovsky (1965) for 24 hours. After this period, the plant material was prewashed in phosphate buffer $(0.1 \mathrm{M}, \mathrm{pH} 7.2)$, dehydrated with an increasing ethanol series $(30 \%$ a $100 \%$ ), pre-infiltrate and infiltrated in historesin (Leica, Germany), as recommended by the manufacturer. The samples were subsequently transversely sectioned into $5 \mu \mathrm{m}$ thickness on a rotating microtome (Model I508R, Logen Scientific, China) and the sections were stained with toluidine blue - polychromatic coloration $(0.05 \%$ phosphate buffer 0.I M, pH 6.8) (O’Brien et al., 1964). The images were obtained with an Olympus microscope (BX6I, Tokyo, Japan) coupled with a DP-72 camera using the clear field option. Morphoanatomic observations were then carried out on the epidermis, the adaxial and abaxial surfaces, as well as on palisade, spongy and mesophilic parenchyma. 


\section{Statistical analysis}

The experimental data were analyzed according to the basic statistical assumptions, ascertaining their normality and homogeneity. Analyses of variance (at $5 \%$ significance) were performed, and the means were separated by the Scott-Knott test. The computer program SISVAR 5.3 was used (Ferreira, 20I I).

\section{RESULTS}

\section{Biometric and biomass assessments}

The results regarding shoot height at 120 days indicated that treatments with osmocote and with mineral fertilization influenced seedling growth, while treatments 6, 7 and 8 presented superior height and diameter in relation to the other treatments, showing, in general, that the effect of slow-release fertilization was lower than the effect of weekly fertilization (Figure I). It can be observed that all $110 \mathrm{~cm}^{3}$ tubes reached higher averages for plant height and diameter, highlighting the treatments that were fertilized weekly (Figure I). The $100 \mathrm{~cm}^{3}$ tubes with higher doses of slow-release fertilization presented similar results to treatment with cover fertilization, $\mathrm{T} 4=\mathrm{T} 5=\mathrm{T} 7$.
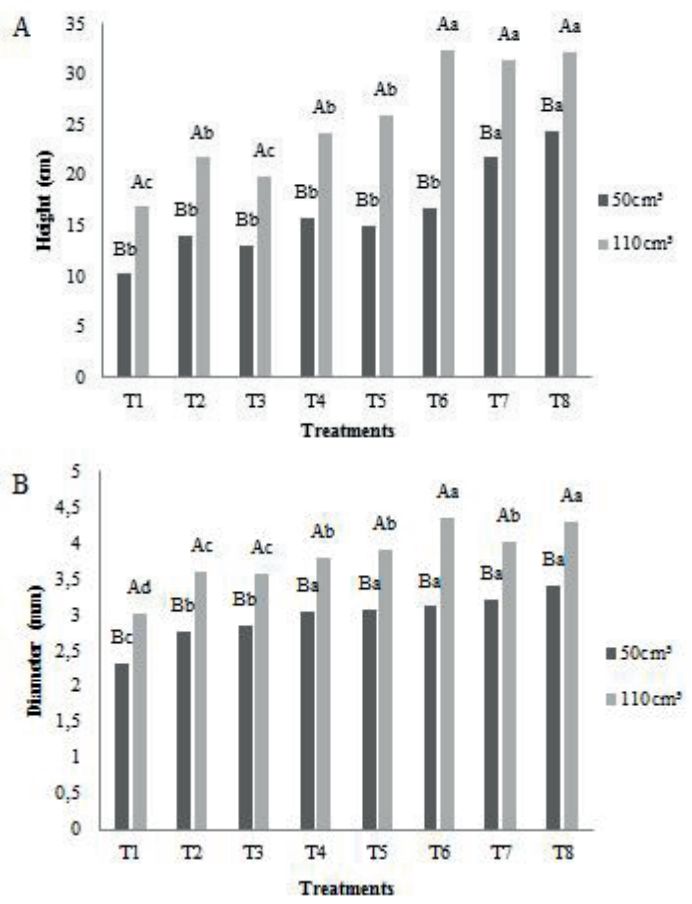

FIGURE I Measurements of Acrocarpus fraxinifolius plants at 120 days of cultivation in tubes of 50 and $110 \mathrm{~cm}^{3}$ with different fertilizations. Height $(A)$ and diameter (B). Means with different letters differ significantly by the Scott Knott test at 5\% significance, uppercase letters differ regarding tube size and lowercase letters differ regarding treatment.

\section{Gas exchanges}

For the analysis of photosynthetic rate $(A)$, stomatal conductance $(\mathrm{gs})$ and transpiration $(E), 110 \mathrm{~cm}^{3}$ tubes were similar to $50 \mathrm{~cm}^{3}$ tubes (Figure 2A-C) with emphasis to the tubes of $50 \mathrm{~cm}$ the treatments with weekly fertilization tended to present better results, since they present a lower consumption of substrate and a physiological quality equal to or superior to the other treatments (Figure 2). The relationship between internal and external $\mathrm{CO}_{2}(\mathrm{C} /$ $\mathrm{C}_{\mathrm{a}}$ ) (Figure 2D) only presented a difference for Treatment 8 when compared to the other treatments and tube volumes. For the $\left(A / C_{i}\right)$ ratio, the results found are similar to the photosynthetic rates, with higher values for the treatments with osmocote and fertilizers.

Means with different letters differ significantly by the Scott Knott test at $5 \%$ significance, uppercase letters differ regarding tube size and lowercase letters differ regarding treatment.

\section{Fluorescence of chlorophylla}

The potential quantum yield of photosystem II $(\mathrm{Fv} / \mathrm{Fm})$ among the treatments did not suffer any type of damage that interfered with plant development (Figure 3A). Treatment 7 presented the highest means in relation to the type of fertilization and size of the tube for the electron transport rate (ETR) (Figure 3B). The relationship of the ETR with photosynthesis showed an increase of the means for treatments 4 and 7 (Figure 3C). The non-photochemical extinction coefficient (NPQ) presented no difference between treatments and tube volumes (Figure 3D).

\section{Morphoanatomical leaf characterization}

The adaxial and abaxial faces of the leaf epidermis in Acrocarpus fraxinifolius consist of isodiametric cells with flat or slightly convex anticline walls. The mesophyll is dorsiventral, composed of one or two layers of palisade parenchyma formed by elongated cells, in which crystalline idioblasts containing calcium oxalate drusen can be evidenced. The spongy parenchyma have three to four layers of cells, which exhibit irregular shapes and reduced intercellular spaces. Acrocarpus fraxinifolius growth in $50 \mathrm{~cm}^{3}$ tubes resulted in an expansion of the parenchyma cells with greater mesophyll thickness among all treatments when compared to the control (Figure 4). Similar results were observed for the $100 \mathrm{~cm}^{3}$ tubes; however, treatments I and 5 showed a lower thickness of the mesophyll compared to the others (Figure 4 IIA-E). 

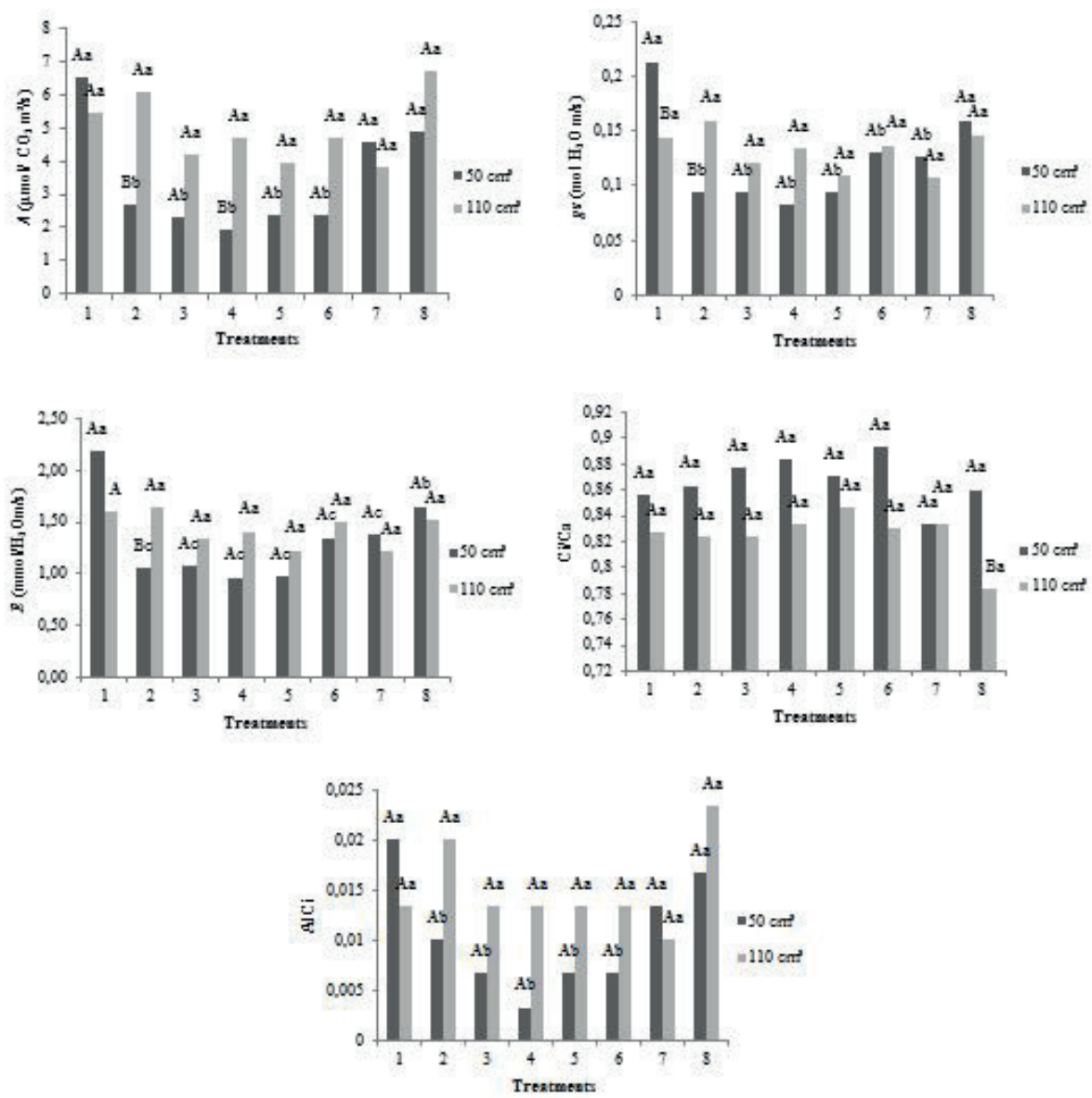

FIGURE 2 Gas exchange in Acrocarpus fraxinifolius at I 20 days of cultivation in 50 and $110 \mathrm{~cm}^{3}$ tubes with different fertilizations (A), liquid photosynthetic rate (A), (B) stomatal conductance (gs), (C) transpiration (E), (D) relationship between internal and external $\mathrm{CO}_{2}$ concentration $(\mathrm{Ci} / \mathrm{Ca}),(\mathrm{E})$ photosynthetic rate between internal $\mathrm{CO}_{2}$ concentration $(\mathrm{A} / \mathrm{Ci})$.
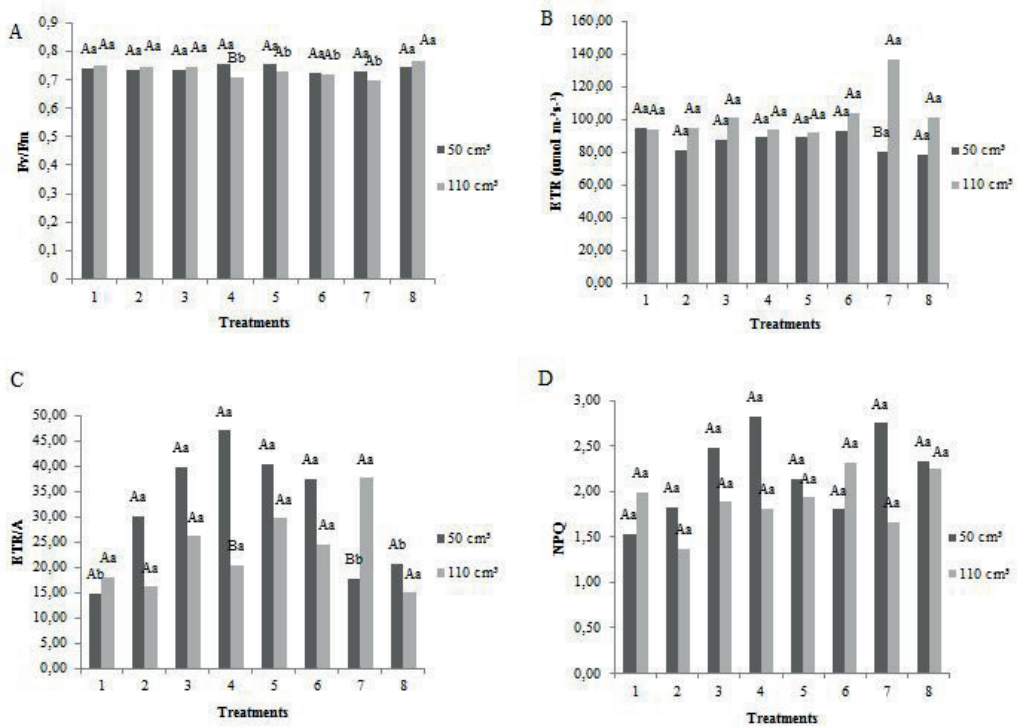

FIGURE 3 Fluorescence of chlorophyll a in Acrocarpus fraxinifolius at 120 days of cultivation in 50 and $110 \mathrm{~cm}^{3}$ tubes with different fertilizations. Quantum potential yield of photosystem II (Fv/Fm) (A), electron transport rate (ETR) (B), relationship between the apparent electron transport rate and $\mathrm{CO}_{2}$ assimilation (ETR/A) (C), non-photochemical extinction coefficient (NPQ) (D). Means with different letters differ significantly by the Scott Knott test at $5 \%$ significance, uppercase letters differ regarding tube size and lowercase letters differ regarding treatment. 


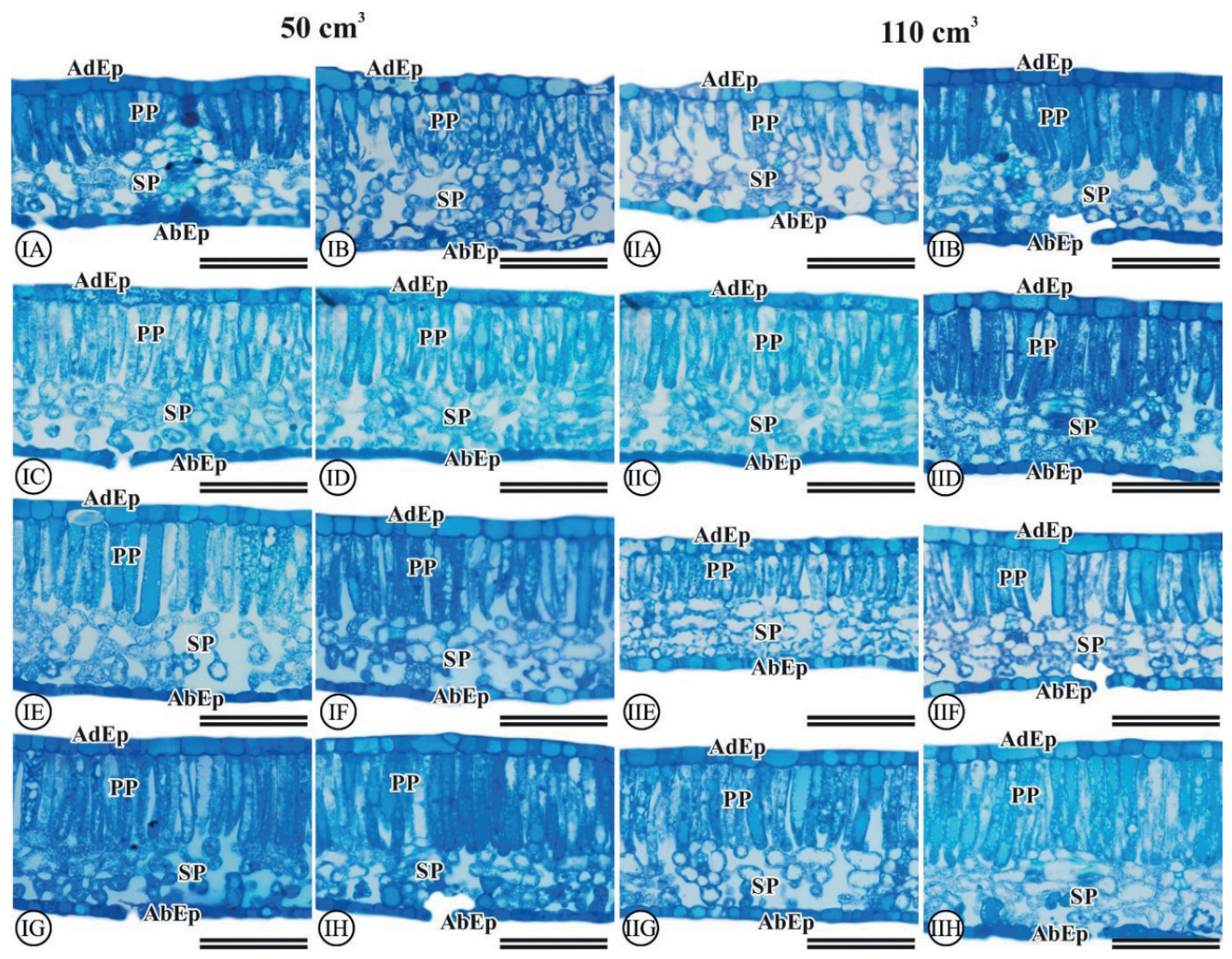

FIGURE 4 Anatomical changes in Acrocarpus fraxinifolius leaves after 120 days of cultivation in 50 and II0 $\mathrm{cm}^{3}$ tubes with different fertilizations. (Adep) adaxial epidermis. (Abep) abaxial epidermis. (PP) palisade parenchyma. (SP) spongy parenchyma. (IA-IIA) TI, (IB-IIB) T2, (IC-IIC) T3, (ID-IID) T4, (IE-IIE) T5, (IF-IIF) T6, (IG-IIG) T7, (IH-IIH) T8. I Scale bar I00 $\mu \mathrm{m}$.

\section{DISCUSSION}

A. fraxinifolius plants show increased growth and stem diameter when grown in $110 \mathrm{~cm}^{3}$ tubes. Highervolume containers tend to deliver and store larger amounts of nutrients and water, aiding in plant growth and development (Lisboa et al., 20I2). Corroborating this study, Dias et al. (2016) reported that Sapindus saponaria, Ceiba speciosa, Guazuma ulmifolia and Schinus terebintifolius seedlings presented greater development and growth in $120 \mathrm{~cm}^{3}$ tubes compared to smaller tubes. Seedling height is a factor that is used as an indicator of seedling survival and development, and nutrients such as nitrogen may help in this index. In our study, the treatments which were fertilized weekly showed higher height indexes. The $\mathrm{N}$-promoting effect on these growth parameters can be explained by the fact that the $\mathrm{N}$ supply increases the number of meristematic cells promoting the highest plant growth (Lawlor, 2002). Therefore, it is evident that $\mathrm{N}$ is involved directly or indirectly in the increase and division of new cells and in the production of tissues, which, in turn, are responsible for the increase of the growth characteristics.
Photosynthetic rate $(A)$, stomatal conductance (gs) and transpiration $(E)$ of $A$. fraxinifolius in $110 \mathrm{~cm}^{3}$ tubes were similar to well-fertilized $50 \mathrm{~cm}^{3}$ tubes. Positive results for $A$ and gs in relation to fertilization rich in nitrogen are due to the greater biosynthesis of photosynthetic components, of which $\mathrm{N}$ is constituent, such as the Rubisco enzyme and the chlorophyll molecule (Pompeu et al., 2010). There is a direct relationship between gs and $A$, in which an increase of gs promotes an increase in $A$ (Lima Júnior et al., 2006). On the other hand, plant growth restriction can be associated with reductions in the photosynthetic rate, either by stomatal or non-stomatal effects (Figueiredo et al., 2014). Thus, smaller tubes may present lower photosynthetic rates when not adequately fertilized, as observed in Treatment 2. The main factors that influence the exit of water from plants to the atmosphere through transpiration as well as the entry and assimilation of $\mathrm{CO}_{2}$ for photosynthesis, are the contents of liquid water present in the soil and in water vapor present in the atmosphere, in addition to morphological characteristics of the species (Abreu et al., 20I5). Therefore, the choice for the container, 
substrates or irrigation control that provide the ideal supply of water and nutrients is fundamental for better plant development. Generally speaking, good quality seedlings in smaller container volumes with adequate fertilization can provide lower costs in the production, transport and implantation of seedlings in the field, the results show that seedlings produced in smaller containers being well fertilized have physiological quality equal to or greater than the larger containers, the whole apparatus for an efficient establishment in the field, these seedlings being cheaper to be produced, transported and planted, thus presenting an advantage for the producer.

The non-photochemical extinction coefficient (NPQ) can be related to the electron transport rate (ETR), in which the thermal dissipation of the excitation energy expressed by non-photochemical extinction showed similar tendencies to those shown by the ETR; thus, an increase in electron transport rate (ETR) in relation to higher plant growth indicates the ability to efficiently use light for photosynthesis (Dias, 2015). The lack of nutrients or producing seedlings in inadequate containers can lead to physiological damage, as plants under stress activate alternative mechanisms to avoid damage in their photosynthetic apparatus, such as the dissipation of electrons by photorespiration (Genty et al., 1989; Arena et al., 2016) and thermal dissipation (Pinnola et al., 20/3). The latter can be observed through increasing NPQ, described as a mechanism of PSII protection against photoinhibition (Liu et al., 2007). However, the effectiveness of the protective mechanisms depends on the stress intensity and physiological characteristics of the plant. The correlation between internal and external $\mathrm{CO}_{2}$ concentrations $(\mathrm{Ci} / \mathrm{Ca})$ linked to the electron transport rate indicate that ATP and NADPH production were affected by fertilization and tube volume. In other words, gaseous exchanges and carbon assimilation allied with photochemical efficiency assessments play a key role in the adaptive response and plasticity of species, which may have direct or additive effects on photosynthesis (Gallé et al., 20I I).

The anatomical characteristics of $A$. fraxinifolius in 50 and $100 \mathrm{~cm}^{3}$ tubes show differences in relation to treatment, as the plants demonstrated expansion of parenchyma cells with greater mesophyll thickness. Mesophyll expansion without altering the parenchyma cells implies greater photosynthetic efficiency; on the other hand, mesophyll cell compaction interferes with carbon distribution, which implies in less photosynthetic efficiency (Akin and Robinson, 1982; Luis et al., 2010). The palisade parenchyma is closely related to photosynthesis, and further development of this tissue may allow greater $\mathrm{CO}_{2}$ fixation. Thus, greater palisade parenchyma thickness is related to a significant increase in the mesophyll volume per leaf area, which can directly influence gas exchange (Voltan et al., 1992).

\section{CONCLUSION}

The use of the different fertilizations and container sizes affect the quality of Acrocarpus fraxinifolius seedlings. The morphological and physiological characteristics demonstrated that the $100 \mathrm{~cm}^{3}$ tube presents good quality in all fertilization treatments and $50 \mathrm{~cm}^{3}$ tubes with split fertilization in treatments 7 and 8 provided quality seedlings. Thus, the use of $50 \mathrm{~cm}^{3}$ tubes with fertilization treatment 7 is recommended for producing A. fraxinifolius seedlings, due to presenting physiological quality equal to or better to the best treatments and economy of inputs in nursery production, transportation and planting.

\section{REFERENCES}

ABREU, M. C.; MARTINS, F. B.; FREITAS, C. H.; PEREIRA, R. A. de A.; MELLONI, E. G. P. Valores limítrofes para transpiração, desenvolvimento e crescimento de Corymbia citriodora (Hook.) K. D. Hill \& L.A.S. Johnson em resposta à deficiência hídrica no solo. Revista Árvore, v. 39, n. 5, p. 84I-852, 2015.

AKIN, D. E.; ROBINSON, E. L. Estrutura de folhas e hastes de seta e pinça de trevo como relacionada à digestibilidade in vitro. Crop Science, v. 22, p. 24-29. 1982.

ARENA, C.; TSONEV, T.; DONEVA, D.; MICCO DE, V.; MICHELOZZI, M.; BRUNETTI, C.; CENTRITTO, M.; FINESCHI, S.; VELIKOVA, V.; LORETO, F. The effect of light quality on growth, photosynthesis, leaf anatomy and volatile isoprenoids of a monoterpene-emitting herbaceous species (Solanum lycopersicum L.) and an isopreneemitting tree (Platanus orientalis L.). Environmental and Experimental Botany, v. I30, p. |22-132. 2016.

BAMBERG, R.; CARON, B. O.; SCHMIDT, D.; SOUZA, V. Q. de; BEHLING, A. Determinação do filocromo em mudas de eucalipto em função do volume do tubete e da densidade de plantas. Enciclopédia Biosfera, v. 8, n. I5, p. 629,2012

BILGER, W.; BJÖRKMAN, O. Role of xanthophyll cycle in photoprotection elucidated by measurements of light induced absorbance changes, fluorescence and photosynthesis in leaves of Hedera canariensis. Photosynthesis Research, v. 25, p. 73-185. 1990.

BRASIL. Ministério da agricultura. Normais climatológicas I96I - 1990. Brasília, 1992. 84p. 
CAIONE, G.; LANGE, A.; SCHONINGER, E. L. Crescimento de mudas de Schizolobium amazonicum (Huber ex Ducke) em substrato fertilizado com nitrogênio, fósforo e potássio. Scientia Forestalis, v. 40, p. 213-221. 2012.

DIAS, A. N. Capacidade de aclimatação à luz no estabelecimento inicial de macaúba (Acrocomia aculeata (Jacq.) Lood. Ex Mart.) em condições de viveiro e em campo. 20।5. 72 p. Dissertação de mestrado. Universidade Federal de Viçosa.

DIAS, I. M.; BARRETO, I. D. de C.; FERREIRA, R. A. Efeito de dosagens de fertilizantes fosfatado na determinação de volume ótimo de produção de mudas de espécies florestais nativas. Scientia Agraria Paranaensis, v. 15, n. 14, p. $47 \mid-475,2016$.

DINALLI, R. P.; CASTILHO, R. M. M. de; GAZOLA, R. de N. Utilização de adubos de liberação lenta na produção de mudas de Vigna radiata L. Revista Científica Eletrônica de Agronomia, v.2I, n. I, p.I0-15, 2012.

FERREIRA, D. F. Sisvar: a computer statistical analysis system. Ciência e Agrotecnologia, v. 35, n.6, p. I039 - 1042, 201 I.

FIGUEIREDO, F. A. M. M. de A.; CARNEIRO, J. G. de A.; PENCHEL, R. M.; CAMPOSTRINI, E.; THIEBAUT, J. T. L.; BARROSO, D. G. Trocas gasosas, relações hídricas e eficiência fotoquímica em mudas clonais de eucalipto com permanência prolongada em tubetes. Scientia Forestalis, v. 42, n. 104, p. 533-542, 2014.

FIRMINO, A. C.; MORAES, W. B.; FURTADO, E. L. Primeiro relato de Ceratocystisfimbriata causando seca em Acrocarpus fraxinifolius no Brasil. Summa Phytopathol, 4I, n. 2, p. 160, 2015.

GALLÉ, A.; FLOREZ-SARASAL, I.; AOUOUADL, H. E.; FLEXAS, J. The Mediterranean evergreen Quercus ilex and the semi deciduous Cistus albidus differ in their leaf gas exchange regulation and acclimation to repeated drought and re-watering cycles. Journal of Experimental Botany, v. 62 , n. I, p. I-10, $201 \mathrm{I}$.

GONÇALVES, J. L. M.; BENEDETTI, V. Nutrição e fertilização florestal. Piracicaba: IPEF, 2005. 427p.

INMET. Instituto nacional de meteorologia. 20I2. http:// www.inmet.gov.br/sonabra/pg_dspDadosCodigo_sim. php?QTAyNQ. Acesso em 04 de outubro de 2018.

KARNOVSKY, M. J. A. Formaldehyde-glutaraldehyde fixative of high osmolarity for use in electron microscopy. Journal Cell Biology, v. 27, p. 137 - 138, 1965.

KLIPPEL, V. H.; PEZZOPANE, J. E. M.; PEZZOPANE, J. R. M.; CECÍLIO, R. A.; CASTRO, F. da S.; PIMENTA, L. R. Zoneamento climático para teca, cedro australiano, nim indiano e pupunha no estado do Espírito Santo. Revista Floresta, v. 43, n. 4, p. 67I - 680, 2013.
LAISK, A.; Loreto, F. Determining photosynthetic parameters from leaf $\mathrm{CO}_{2}$ exchange and chlorophyll fluorescence. Plant Physiology, v. I I0, p. 903-9I. 1996.

LAWLOR, D.W. Carbon and nitrogen assimilation in relation to yield: mechanisms are the key to understanding production systems. Journal of Experimental Botany. v. 53, p. 773787, 2002.

LISBOA, A. C.; SANTOS, P. S. dos; OLIVEIRA NETO, S. N. de; CASTRO, D. N. de; ABREU, A. H. M. de. Efeito do volume de tubetes na produção de mudas de Calophyllum brasiliense e Toona ciliata. Revista Árvore, v. 36, n. 4, 2012.

LUIS, Z. G.; BEZERRA, K. M. G.; PEREIRA, J. E. S. Adaptability and leaf anatomical features in oil palm seedlings produced by embryo rescue and pre-germinated seeds. Brazilian Journal of Plant Physiology, v. 22, p. 209-2 I5. 2010.

LIU, J.; ZHOU, G.; YANG, C.; OU, Z.; PENG, C. Responses of chlorophyll fluorescence and xanthophyll cycle in leaves of Schima superba Gardn e Champ. and Pinus massoniana Lamb, to simulated acid rain at Dinghushan biosphere. China. Acta Physiologiae Plantarum, v. 29, p. 33-38. 2007.

NISGOSKI, S.; TRIANOSKI, R.; MUÑIZ, G. I. B. de.; MATOS, J. L.M. de.; STYGAR, M. Variação radial das estruturas da madeira de Acrocarpus fraxinifolius Wight \& Arn. Floresta e Ambiente, v. 19, p. 316-324. 2012.

PINNOLA, A.; DALL'OSTO, L.; GEROTTO, C.; MOROSINOTTO, T.; BASSI, R.; ALBORESI, A. Zeaxanthin binds to light-harvesting complex stress-related protein to enhance nonphotochemical quenching in Physcomitrella patens. Plant Cell. v. 25, p. 3519-3534. 2013.

POMPEU, R. C. F. F.; CÂNDIDO, M. J. D.; LOPES, M. N.; GOMES, F. H. T.; LACERDA, C. F; AQUINO, B. F; MAGALHÃES, J. A. Características morfofisiológicas do capim-aruana sob diferentes doses de nitrogênio. Revista Brasileira de Saúde e Produção Animal, v.ll, n.4, p.II87- I210, 2010.

RAI, S. N. Pre-treatment of Acrocarpus fraxinifolius seeds. Indian-Forester, v. 102, p. 488-49I. 1976.

RUDAWSKA, M.; LESKI, T.; AUC ${ }^{\sim} I N A$, A.; KARLINSKI, L.; SKRIDAILA, A.; RYLIŠKIS, D. Forest litter amendment during nursery stage influence field performance and ectomycorrhizal community of Scots pine (Pinus sylvestris L.) seedlings outplanted on four different sites. Forest Ecology and Management. v. 395, p. I04-1 14. 2017.

SIMÕES, P. H. O.; PALHETA, L. F;; VALE, R. S. do; CORREIRA, R. G.; NEVES, R. L. P. Crescimento e qualidade de mudas de castanheira-do-Brasil (Bertholletia excelsa Bonpl.Lecythidaceae) em substratos fertilizados commacronutrientes. Enciclopédia Biosfera, v. I I n. 2I, p.689, 2015.

THEBALDI, M. S.; LIMA, L. A.; COLARES, M. de F. B.; SILVA, A. C. da.; LIMA, P. L. T. Dinâmica das características químicas de um substrato florestal exposto à irrigação. Ciência Florestal, v. 25, n. 2, p. 375-384, 2015. 
TRIANOSKI, R.; IWAKIRI, S.; MATOS, J. L. M de; PRATA, J. G. Viabilidade da utilização de Acrocarpus fraxinifolius em diferentes proporções com Pinus spp. para produção de painéis aglomerados. Scientia Forestalis, v. 39, n. 91, p. 343-350, 2011.

TURCHETTO, F; ARAUJO, M. M.; TABALDI, L. A.; GRIEBELER, A. M.; RORATO, D. G.; AIMI, S. C.; BERGHETTI, A. L. P.; GOMES, D. R. Can transplantation of forest seedlings be a strategy to enrich seedling production in plant nurseries?. Forest Ecology and Management, v.375, p. 96-104. 2016.
VENTURIN, N.; CARLOS, L. SOUZA, P. A. de; MACEDO, R. L. G.; VENTURIN, R. P. HIGASHIKAWA, E. M. Desempenho silvicultural de Acrocarpus fraxinifolius Wight em função de diferentes espaçamentos e idades. Cerne, v. 20, p. 629636, 2014.

VOLTAN, R. B. Q.; FAHL, J. I.; CARELLI, M. L. C. Variação na anatomia foliar de cafeeiro submetidos a diferentes intensidades luminosas. Revista Brasileira de Fisiologia Vegetal, v. 4, n. 2, p. 99-105, 1992. 